\section{Tolerance of Strawberry Cultivars to Oxyfluorfen and Flumioxazin Herbicides}

\author{
Jayesh B. Samtani ${ }^{1}$, J. Ben Weber, and Steven A. Fennimore \\ Department of Plant Sciences, University of California-Davis, 1636 East \\ Alisal Street, Salinas, CA 93905 \\ Additional index words. Fragaria $\times$ ananassa, weed control, methyl bromide alternative, crop \\ injury
}

\begin{abstract}
Herbicides can be an excellent supplemental treatment in cases where soil fumigant treatments alone fail to control weeds during the growing season or in situations where fumigants cannot be used as a result of regulatory restrictions. Previous studies have shown that oxyfluorfen and flumioxazin can provide satisfactory weed control in bedded strawberry (Fragaria Xananassa Duch.) production. However, we need to know if tolerance to herbicides is uniform across strawberry cultivars under California conditions. The objective of this study was to determine if tolerance to oxyfluorfen and flumioxazin herbicides varied among strawberry cultivars. Trials were conducted in the 2007-2008 and 2009-2010 growing seasons at Salinas, CA. Treatments included an untreated control; pre-plant applications of flumioxazin at $0.07,0.11$, and $0.21 \mathrm{~kg} \cdot \mathrm{ha}^{-1}$ a.i.; and oxyfluorfen at 0.14 and $0.28 \mathrm{~kg} \cdot \mathrm{ha}^{-1}$ a.i. The entire trial was fumigated with an emulsified formulation of $60 \%$ 1,3-dichloropropene $+32 \%$ chloropicrin applied at $281 \mathrm{~L} \cdot \mathrm{ha}^{-1}$ by drip injection to all plots. Eight strawberry cultivars were included in the trial in the 2007-2008 growing season, and nine cultivars were included in the 2009-2010 growing season. In both growing seasons, slight to no crop phytotoxicity was observed. In the 2007-2008 growing season, several strawberry cultivars including 'Albion', 'Festival', '211G51', 'Palomar', 'Plant Sciences 5298', and 'Ventana' had smaller crop plant canopy diameter as compared with the control when treated with $0.21 \mathrm{~kg} \cdot \mathrm{ha}^{-1}$ a.i. of flumioxazin. Compared with the control, flumioxazin at $0.21 \mathrm{~kg} \cdot \mathrm{ha}^{-1}$ a.i. reduced crop diameter for 'Plant Sciences 4634', 'Plant Sciences 5298', 'San Andreas', and 'Ventana' in the 2009-2010 growing season. In the 2007-2008 strawberry-growing season, none of the herbicide treatments reduced fruit yield compared with the control. In the 2009-2010 growing season, in seven of the nine cultivars, there were no significant differences in yield among treatments. For 'Palomar' strawberry, yields in plots treated with flumioxazin at 0.11 and $0.21 \mathrm{~kg} \cdot \mathrm{ha}^{-1}$ a.i. were significantly lower than the untreated control. With the exception of flumioxazin at $0.21 \mathrm{~kg} \cdot \mathrm{ha} \mathrm{a}^{-1} \mathrm{a}$.i., these herbicides are safe to use and can be incorporated in strawberry production practices for the cultivars tested to achieve satisfactory weed control over the growing season.
\end{abstract}

The United States is the world's largest producer of strawberries (Fragaria $\times$ ananassa Duch.) with total production in 2010 valued at $\$ 2.2$ billion, of which California's contribution is $\$ 1.8$ billion [Agricultural Marketing Resource Center (AMRC), 2011]. Of the 23,541 ha of land under strawberry production in the United States, 15,621 ha were in California (U.S. Department of AgricultureNational Agricultural Statistics Survey, 2011). Within California, most production occurs in the southern and central coastal areas with a growing season typically lasting 10 to 15 months (AMRC, 2011). Weeds are a threat to strawberry, particularly during the early

Received for publication 27 Feb. 2012. Accepted for publication 3 May 2012

The California Strawberry Commission provided funding for this project.

We thank John Rachuy and Yesenia Martinez for their help with the study.

${ }^{1}$ To whom reprint requests should be addressed; e-mail safennimore@ucdavis.edu. et al., 2009). Hand weeding the fields increases production costs and has little effect on weeds such as nutsedge. Herbicides can help keep the weed populations down while maintaining the profitability of strawberry production. Potential use of herbicides includes sensitive border and buffer areas where the use of fumigants is restricted, new ground being used for strawberry production that has high weed pressure, and the furrow area in between raised beds that are typically non-fumigated (Fennimore et al., 2005).

Both flumioxazin and oxyfluorfen herbicides are registered for strawberry production in California, and each product was used on over 2000 ha of strawberry in 2010 (California Department of Pesticide Regulation, 2012; Daugovish et al., 2009). Flumioxazin at 0.07 and $0.11 \mathrm{~kg} \cdot \mathrm{ha}^{-1}$ a.i can be applied to the raised bed $30 \mathrm{~d}$ before strawberry transplanting, and film installation must occur before time of transplanting (Valent U.S.A. Corporation, 2011). Manning and Fennimore (2001) found that overtop application of flumioxazin at $0.07 \mathrm{~kg} \cdot \mathrm{ha}^{-1}$ a.i. was safe on 'Camarosa' and 'Selva' strawberries when made immediately after transplanting. When applied to the bed top at 0.07 and $0.11 \mathrm{~kg} \cdot \mathrm{ha}^{-1}$ a.i. rates greater than $30 \mathrm{~d}$ before transplanting, flumioxazin effectively controlled little mallow (Malva parviflora L.) and clover (Medicago sp.) without causing any phytotoxicity on strawberry (Fennimore et al., 2005). However, when flumioxazin was applied 2 and $14 \mathrm{~d}$ pre-transplant at $0.21 \mathrm{~kg} \cdot \mathrm{ha}^{-1}$ a.i., slight plant injury and reduced yields were observed, particularly for the 2 -d pre-transplant treatment (Fennimore and Ajwa, 2003).

For oxyfluorfen, a minimum $30-\mathrm{d}$ period from soil treatment to planting strawberries is recommended at rates of up to $0.6 \mathrm{~kg} \cdot \mathrm{ha}^{-1}$ a.i. (Dow AgroSciences LLC, 2011). Oxyfluorfen at 0.3 to $0.6 \mathrm{~kg} \cdot \mathrm{ha}^{-1}$ a.i. reduced weeding times by $37 \%$ to $63 \%$ compared with the untreated control, and provided satisfactory control of broadleaf weeds including California burclover, hairy nightshade [Solanum villosum (L.) Mill.], little mallow, shepherd's purse [Capsella bursa-pastoris (L.) Medik.], and clovers (Daugovish et al., 2008, 2009). Stall et al. (1995) found pre-emergence oxyfluorfen application at 0.3 and $0.6 \mathrm{~kg} \cdot \mathrm{ha}^{-1}$ did not affect strawberry vigor and provided season-long control of weeds including Carolina geranium (Geranium carolinianum L.) and cutleaf evening primrose (Oenotheria laciniata Hill.). Oxyfluorfen at $0.6 \mathrm{~kg} \cdot \mathrm{ha}^{-1}$ a.i. + napropamide at $4.5 \mathrm{~kg} \cdot \mathrm{ha}^{-1}$ a.i. applied $21 \mathrm{~d}$ before transplanting 'Camarosa' strawberry increased fruit weight by $20 \%$ compared with untreated control (Gilreath and Santos, 2005). Pre-plant oxyfluorfen application at $0.6 \mathrm{~kg} \cdot \mathrm{ha}^{-1}$ a.i. controlled weeds similar to MB-Pic standard soil fumigation with no crop injury on 'Albion' strawberry (Samtani et al., 2011).

Oxyfluorfen has the potential to injure plants through codistillation or "lift off," a process in which the herbicide moves with water vapor from soil surface to strawberry foliage (Fennimore et al., 2008). Splashing of 
the herbicide from the soil to strawberry crown and foliage during an irrigation event can also potentially injure the crop (Fennimore et al., 2008). These injuries through splashing and codistillation can be reduced by film installation on the bed before strawberry transplanting (Daugovish et al., 2009).

The objective of this study was to determine if tolerance to flumioxazin and oxyfluorfen herbicide varied among strawberry cultivars. Many of the cultivars evaluated in the study ('Albion', 'Camarosa', 'Palomar', 'San Andreas', 'Ventana') are public cultivars bred by University of California and are commonly grown in the state on over 12,141 ha (Shaw and Larson, 2008; [California Strawberry Commission (CSC), 2011]. 'Festival' is a short-day cultivar released by Florida Foundation Seed Producers (North Carolina Crop Improvement Association, 2012). Private and other cultivars account for over $40 \%$ of the state's acreage (CSC, 2011). The cultivars 273M171, 211G51, and 49C129 are propriety. The Plant Sciences 5298 and 4634 cultivars are also proprietary, bred by Plant Sciences, Inc. for California and other international locations (Plant Sciences Inc., 2012).

\section{Materials and Methods}

Trials were conducted in the 2007-2008 and 2009-2010 growing seasons at the U.S. Department of Agriculture-ARS research facility in Salinas, CA (lat. $36^{\circ} 4^{\prime} \mathrm{N}$, long. $121^{\circ} 3^{\prime}$ $\mathrm{W}$, elevation $\approx 47 \mathrm{~m}$ ). The soil at the trial site was a Chualar sandy loam (fine loamy, mixed, thermic, Typic Argixeroll) with a $\mathrm{pH}$ of 6.5 and organic carbon content of $0.7 \%$.

2007-2008 growing season. The trial was established in Oct. 2007 in a randomized complete block design with six treatments and four replicates. Each replicate plot was a $1.3 \mathrm{~m}$ wide $\times 3.1-\mathrm{m}$ long bed for each cultivar. Treatments included flumioxazin $\left(\right.$ Chateau ${ }^{\circledR}$ Herbicide SW; Valent, Walnut Creek, CA) applied at $0.07,0.11$ and $0.21 \mathrm{~kg} \cdot \mathrm{ha}^{-1}$ a.i. on 5 Oct. and oxyfluorfen (GoalTender ${ }^{\circledR}$; Dow AgroSciences LLC, Indianapolis, IN) applied at 0.14 and $0.28 \mathrm{~kg} \cdot \mathrm{ha}^{-1}$ a.i. on 4 Oct. Herbicides were applied using a handheld $\mathrm{CO}_{2}$ backpack sprayer-powered spray boom operating at $241 \mathrm{kPa}$. Use rates of flumioxazin labeled for strawberry are 0.07 and $0.11 \mathrm{~kg} \cdot \mathrm{ha}^{-1}$, but the $0.21 \mathrm{~kg} \cdot \mathrm{ha}^{-1}$ rate was included to test the tolerance of strawberry to the $2 \times$ dose rate.
The entire trial was treated on 5 Oct. with $2 \%$ $\mathrm{v} / \mathrm{v}$ glyphosate (Roundup Ultra ${ }^{\circledR}$; Monsanto, St. Louis, MO) to kill any emerged weeds. The trial was then covered with a clear polyethylene film (Guardian $1.4 \mathrm{~mL}$; Guardian AgroPlastics, Tampa, FL) and fumigated with emulsified formulation of 1,3-D + Pic (InLine $^{\mathrm{TM}}, 60 \%$ 1,3-D and 32\% Pic; Indianapolis, IN) applied at $281 \mathrm{~L} \cdot \mathrm{ha}^{-1}$ by drip injection to all plots on 10 Oct. 2007. Irrigation in the beds was supplied by two drip tapes (Toro Ag, El Cajon, CA) spaced $13 \mathrm{~cm}$ apart and placed at a soil depth ranging from 2 to $5 \mathrm{~cm}$. Drip emitters were spaced $30 \mathrm{~cm}$ apart and the flow rate was $1 \mathrm{~L} \cdot \mathrm{h}^{-1}$ at $70 \mathrm{kPa}$. Eight strawberry cultivars included in the trial were 'Albion', 'Camarosa', 'Festival', '211G51', 'Palomar', 'Plant Sciences 5298', '49C129', and 'Ventana'. Transplanting dates were 8 Nov. 2007 for all strawberry cultivars except '211G51', which was transplanted on 10 Dec. 2007. A total of 20 plants per cultivar were planted in each replicate plot. Assessments during the season included estimates of herbicide injury to strawberry $(0=$ no crop injury, $10=$ dead plant) on 24 Jan. 2008, strawberry plant diameters on 1 Apr. 2008, and fruit yield harvest data collected from 18 Apr. through 22 Aug. 2008 on all plants included for each cultivar. Cultural practices of the commercial grower were followed during the growing season.

2009-2010 growing season. This trial was initiated with pre-transplant applications of the flumioxazin and oxyfluorfen treatments on 10 Oct. 2009. Experimental design, treatments, replicate number, plot size, and treatment application method were the same as the 2007-2008 growing season. No glyphosate application was done in the 2009-2010 growing season, but the entire trial was fumigated with 1,3-D + Pic, similar to the 2007-2008 growing season. Nine cultivars of strawberries evaluated were 'Albion', 'Camarosa', '273M171', 'Palomar', 'Plant Sciences 4634', 'Plant Sciences 5298', 'San Andreas', '49C129', and 'Ventana'. Twenty plants of each cultivar were planted on 9 and 10 Nov. 2009 in each replicate plot. As a result of limited availability of the plant material, 12 plants for 'Camarosa' and 'San Andreas' and 10 plants for 'Palomar' cultivars were included per replicate. Estimates of herbicide injury on strawberry were recorded using a rating scale of 0 to $10(0=$ no crop injury, $10=$ dead plant) on 18 Dec. 2009. Crop plant canopy diameter was measured from 22 Mar. through 26 Mar. 2010. Fruit harvest data were collected from 29 Mar. through 18 Oct. 2010.

Statistical analysis. Depending on the availability of cultivars, a slightly different varietal selection was evaluated in the two growing seasons. Hence, data for the two growing seasons were analyzed separately. Data were analyzed using PROC MIXED in SAS (Release 9.1; SAS Institute Inc., Cary, NC). Mean comparison was performed using Fisher's protected least significant differences $(P \leq 0.05)$.

\section{Results and Discussion}

Little injury was observed on any of the strawberry cultivars in either season (Tables 1 and 2). In the 2007-2008 growing season, 'Ventana' strawberry was slightly injured by flumioxazin at $0.11 \mathrm{~kg} \cdot \mathrm{ha}^{-1}$ a.i., compared with the untreated control (Table 1). 'Albion' treated with oxyfluorfen at either dose also had more injury than the untreated control. In the 2009-2010 growing season, minor injury was observed on 'Camarosa' strawberry at both oxyfluorfen rates, but these injury estimates were not significantly different from the ratings of flumioxazin at 0.11 and $0.21 \mathrm{~kg} \cdot \mathrm{ha}^{-1}$ a.i. (Table 2).

In the 2007-2008 growing season, 'Albion', 'Festival', '211G51', 'Palomar', 'Plant Sciences 5298', and 'Ventana' treated with $0.21 \mathrm{~kg} \cdot \mathrm{ha}^{-1}$ a.i. of flumioxazin had smaller plant diameters than the untreated control (Table 3). 'Ventana' treated with flumioxazin at $0.11 \mathrm{~kg} \cdot \mathrm{ha}^{-1}$ had smaller plant diameters than the untreated control. 'Palomar' treated with flumioxazin at $0.07 \mathrm{~kg} \cdot \mathrm{ha}^{-1}$ a.i. and oxyfluorfen at $0.14 \mathrm{~kg} \cdot \mathrm{ha}^{-1}$ a.i. also had smaller plant diameters. In the 2009-2010 growing season, flumioxazin at $0.21 \mathrm{~kg} \cdot \mathrm{ha}^{-1}$ a.i. reduced crop diameter for 'Plant Sciences 4634', 'Plant Sciences 5298', 'San Andreas', and 'Ventana' as compared with untreated control (Table 4). For ' 49 C129', flumioxazin treatments at 0.07 and $0.11 \mathrm{~kg} \cdot \mathrm{ha}^{-1}$ a.i. resulted in the smallest crop canopy diameter; however, these readings were not significantly different from flumioxazin at $0.21 \mathrm{~kg} \cdot \mathrm{ha}^{-1} \mathrm{a}$.i. and oxyfluorfen at $0.14 \mathrm{~kg} \cdot \mathrm{ha}^{-1}$ a.i.

In the 2007-2008 strawberry-growing season, the herbicide treatments did not reduce fruit yields (Table 5). In the 2009-2010 growing season, strawberry yields in eight of the nine cultivars were not significantly reduced

Table 1. Estimates of herbicide injury on eight strawberry cultivars recorded on 24 Jan. 2008 at Salinas, CA.

\begin{tabular}{|c|c|c|c|c|c|c|c|c|c|}
\hline \multirow[b]{2}{*}{ Treatment } & \multirow{2}{*}{$\begin{array}{c}\text { Rate } \\
\text { (kg.ha }{ }^{-1} \text { a.i.) }\end{array}$} & Albion & Camarosa & Festival & $211 \mathrm{G} 51$ & Palomar & Plant Sciences 5298 & $49 \mathrm{C} 129$ & Ventana \\
\hline & & \multicolumn{8}{|c|}{ Injury estimates $(0=$ no crop injury, $10=$ dead plant $)$} \\
\hline Control & 0 & 0.0 & 0.4 & 0.0 & 0.1 & 0.0 & 0.0 & 0.0 & 0.0 \\
\hline Flumioxazin & 0.07 & 0.1 & 0.3 & 0.0 & 0.1 & 0.0 & 0.1 & 0.0 & 0.0 \\
\hline Flumioxazin & 0.11 & 0.1 & 0.0 & 0.1 & 0.3 & 0.0 & 0.0 & 0.0 & $0.4^{*}$ \\
\hline Flumioxazin & 0.21 & 0.3 & 0.0 & 0.3 & 0.3 & 0.0 & 0.1 & 0.0 & 0.0 \\
\hline Oxyfluorfen & 0.14 & $0.5^{* z}$ & 0.1 & 0.1 & 0.0 & 0.0 & 0.0 & 0.0 & 0.1 \\
\hline Oxyfluorfen & 0.28 & $0.6^{*}$ & 0.1 & 0.0 & 0.1 & 0.1 & 0.1 & 0.0 & 0.0 \\
\hline $\begin{array}{l}\text { Least significant } \\
\text { difference } 0.05\end{array}$ & & 0.4 & 0.6 & 0.4 & 0.5 & 0.2 & 0.3 & 0.0 & 0.2 \\
\hline Treatment $P$ values & & 0.0476 & 0.7385 & 0.6546 & 0.8633 & 0.4509 & 0.7008 & 0.0000 & 0.0087 \\
\hline
\end{tabular}

${ }^{\mathrm{z}}$ An asterisk $(*)$ indicates that the treatment is significantly different from the control. 
Table 2. Estimates of herbicide injury on nine strawberry cultivars recorded on 18 Dec. 2009 at Salinas, CA.

\begin{tabular}{|c|c|c|c|c|c|c|c|c|c|c|}
\hline \multirow{2}{*}{ Treatment } & \multirow{2}{*}{$\begin{array}{c}\text { Rate } \\
\left(\mathrm{kg} \cdot \mathrm{ha}^{-1} \text { a.i. }\right)\end{array}$} & Albion & Camarosa & $273 \mathrm{M} 171$ & Palomar & Plant Sciences 4634 & Plant Sciences 5298 & San Andreas & $49 \mathrm{C} 129$ & Ventana \\
\hline & & \multicolumn{8}{|c|}{ Injury estimates $(0=$ no crop injury, $10=$ dead plant $)$} & \\
\hline Flumioxazin & 0.07 & 0.1 & 0.1 & 0.4 & 0.1 & 0.1 & 0.0 & 0.0 & 0.1 & 0.1 \\
\hline Oxyfluorfen & 0.14 & 0.3 & $0.5^{* z}$ & 0.3 & 0.3 & 0.3 & 0.0 & 0.0 & 0.1 & 0.1 \\
\hline Oxyfluorfen & 0.28 & 0.1 & $0.5^{*}$ & 0.5 & 0.0 & 0.0 & 0.1 & 0.0 & 0.1 & 0.0 \\
\hline $\begin{array}{l}\text { Least significant } \\
\text { difference } 0.05\end{array}$ & & 0.3 & 0.3 & 0.3 & 0.2 & 0.3 & 0.2 & 0.0 & 0.3 & 0.3 \\
\hline
\end{tabular}

${ }^{\mathrm{z}} \mathrm{An}$ asterisk $(*)$ indicates that the treatment is significantly different from the control.

Table 3. Strawberry plant canopy diameters recorded on 1 Apr. 2008 at Salinas, CA.

\begin{tabular}{|c|c|c|c|c|c|c|c|c|c|}
\hline & $\begin{array}{r}\text { Rate } \\
\left(\mathrm{kg} \cdot \mathrm{ha}^{-1}\right.\end{array}$ & Albion & Camarosa & Festival & 211G51 & Palomar & $\begin{array}{c}\text { Plant } \\
\text { Sciences } 5298\end{array}$ & $49 \mathrm{C} 129$ & Ventana \\
\hline$\overline{\text { Control }}$ & 0 & 23.5 & 31.0 & 33.8 & 25.3 & 29.5 & 30.3 & 26.7 & 33.5 \\
\hline Flumioxazin & 0.21 & $20.5^{* z}$ & 29.9 & $29.1^{*}$ & $21.7 *$ & $26.7 *$ & $28.3^{*}$ & 26.3 & $30.1^{*}$ \\
\hline Oxyfluorfen & 0.14 & $24.8^{*}$ & 32.3 & 33.1 & $27.5^{*}$ & $28.1 *$ & $32.2 *$ & $25.1 *$ & 34.0 \\
\hline Oxyfluorfen & 0.28 & $25.1 *$ & 32.1 & 32.9 & 26.8 & 29.3 & 31.4 & 27.1 & $35.5^{*}$ \\
\hline Treatment $P$ values & & $<0.0001$ & $<0.0001$ & $<0.0001$ & $<0.0001$ & $<0.0001$ & $<0.0001$ & 0.0145 & $<0.0001$ \\
\hline
\end{tabular}

${ }^{\mathrm{z}} \mathrm{An}$ asterisk (*) indicates that the treatment is significantly different from the control.

Table 4. Strawberry plant canopy diameters recorded from 22 to 26 Mar. 2010 at Salinas, CA.

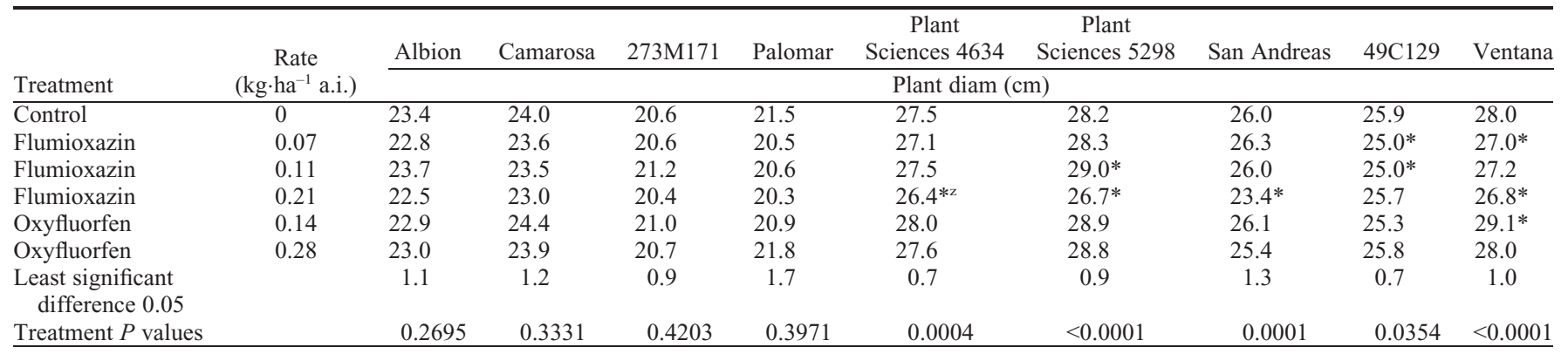

${ }^{\mathrm{z}} \mathrm{An}$ asterisk $(*)$ indicates that the treatment is significantly different from the control.

Table 5. Marketable strawberry fruit yields for the 2007-2008 growing season at Salinas, CA.

\begin{tabular}{|c|c|c|c|c|c|c|c|c|c|}
\hline & $\begin{array}{r}\begin{array}{r}\text { Rate } \\
\left(\mathrm{kg} \cdot \mathrm{ha}^{-1}\right.\end{array} \\
\end{array}$ & Albion & Camarosa & Festival & 211G51 & Palomar & $\begin{array}{c}\text { Plant } \\
\text { Sciences } 5298\end{array}$ & $49 \mathrm{C} 129$ & Ventana \\
\hline Control & 0 & 427.9 & 246.6 & 281.9 & 445.4 & 609.1 & 475.5 & 507.8 & 430.6 \\
\hline Flumioxazin & 0.21 & 409.1 & 241.5 & 278.3 & 364.0 & 552.7 & 468.3 & 493.5 & 457.3 \\
\hline Oxyfluorfen & 0.14 & 479.0 & 256.0 & 257.0 & 402.4 & 496.3 & 604.0 & 365.6 & 453.8 \\
\hline Oxyfluorfen & 0.28 & 548.7 & 261.8 & 271.8 & 376.4 & 564.8 & 557.3 & 439.1 & 521.0 \\
\hline Treatment $P$ values & & 0.2567 & 0.9168 & 0.9880 & 0.6604 & 0.1839 & 0.5082 & 0.0917 & 0.8184 \\
\hline
\end{tabular}

by the herbicides compared with the control (Table 6). For 'Palomar' strawberry, yields in plots treated with flumioxazin at 0.11 and $0.21 \mathrm{~kg} \cdot \mathrm{ha}^{-1}$ a.i. were significantly lower than the untreated control.

Crop phytotoxicity was not an issue when strawberry cultivars were treated with preplant flumioxazin and oxyfluorfen at the dose rates tested, because all treated cultivars had estimated injury ratings of less than 1 . This lack of crop phytotoxicity from oxyfluorfen or flumioxazin treatments is consistent with findings from the other studies (Fennimore and Ajwa, 2003; Fennimore et al., 2005; Samtani et al., 2011). In contrast, Daugovish et al. (2008) reported pre-plant oxyfluorfen application at 0.3 and $0.6 \mathrm{~kg} \cdot \mathrm{ha}^{-1}$ a.i. rates resulted in $9 \%$ to $19 \%$ greater visual crop injury compared with untreated plants, but yields remained unaffected. In this study, only minor crop injury from oxyfluorfen was reported in 'Albion' for the 2007-2008 season and for 'Camarosa' in the 2009-2010 season. When strawberries were treated with flumioxazin at $0.21 \mathrm{~kg} \cdot \mathrm{ha}^{-1}$ a.i., crop diameters were reduced in six of eight cultivars in the 2007-2008 growing season and four of 


\begin{tabular}{|c|c|c|c|c|c|c|c|c|c|c|}
\hline & Rate & Albion & Camarosa & 273M171 & Palomar & $\begin{array}{c}\text { Plant } \\
\text { Sciences } 4634\end{array}$ & $\begin{array}{c}\text { Plant } \\
\text { Sciences } 5298\end{array}$ & $\begin{array}{c}\text { San } \\
\text { Andreas }\end{array}$ & 49C 129 & Ventana \\
\hline Treatment & (kg.ha ${ }^{-1}$ a.i.) & \multicolumn{9}{|c|}{ (g/plant) } \\
\hline Control & 0 & 802.3 & 724.0 & 584.4 & 466.3 & 918.5 & 830.5 & 1045.6 & 735.5 & 528.0 \\
\hline Flumioxazin & 0.07 & 720.8 & 640.3 & 516.6 & 323.0 & 853.8 & 893.1 & 995.7 & 662.3 & 466.5 \\
\hline Flumioxazin & 0.11 & 816.4 & 616.6 & 609.1 & $267.9 * z$ & 906.8 & 884.8 & 1180.8 & 745.2 & 523.0 \\
\hline Flumioxazin & 0.21 & 645.9 & 569.1 & 544.8 & $267.0 *$ & 748.7 & 823.3 & 958.0 & 706.9 & 467.4 \\
\hline Oxyfluorfen & 0.14 & 834.0 & 653.4 & 598.6 & 436.5 & 922.9 & 864.1 & 1145.7 & 773.2 & 638.8 \\
\hline Oxyfluorfen & 0.28 & 714.9 & 628.6 & 554.6 & 474.4 & 844.5 & 859.9 & 1013.9 & 665.1 & 583.4 \\
\hline $\begin{array}{l}\text { Least significant } \\
\text { difference } 0.05\end{array}$ & & 132.3 & 103.6 & 137.7 & 145.0 & 140.8 & 114.6 & 142.0 & 169.1 & 166.1 \\
\hline Treatment $P$ values & & 0.0559 & 0.1100 & 0.7010 & 0.0147 & 0.1342 & 0.7395 & 0.0271 & 0.6734 & 0.2521 \\
\hline
\end{tabular}

${ }^{\mathrm{z}} \mathrm{An}$ asterisk $(*)$ indicates that the treatment is significantly different from the control.

nine cultivars in the 2009-2010 growing season as compared with untreated control. Plant diameters of 'Plant Sciences 5298' and 'Ventana' were reduced in both seasons by the highest rate of flumioxazin. This reduction in plant diameter, however, did not translate or correlate to a yield reduction in the two growing seasons for these cultivars.

All treatments including the control received an application of 1,3-D + Pic to control soil pathogens. A reduction in yield relative to the control in an herbicide-treated plot would have indicated injury from the herbicide. None of the labeled herbicide rates tested, with the exception of flumioxazin at $0.11 \mathrm{~kg} \cdot \mathrm{ha}^{-1}$ a.i. on 'Palomar' in 2009-2010, reduced fruit yields. However, flumioxazin at $0.11 \mathrm{~kg} \cdot \mathrm{ha}^{-1}$ on 'Palomar' in 2007-2008 did not reduce yields relative to the control (Tables 5 and 6 ). Most of the plant canopy reduction was observed with the flumioxazin at $0.21 \mathrm{~kg} \cdot \mathrm{ha}^{-1}$ a.i treatment. The highest flumioxazin rate evaluated in the study is above the labeled rate and cannot be used commercially.

We conclude that labeled rates of oxyfluorfen and flumioxazin herbicides are safe to use on strawberry and can be incorporated in strawberry production practices to achieve satisfactory weed control over the growing season. However, to avoid injury to strawberry, care must be taken when flumioxazin is applied at $0.11 \mathrm{~kg} \cdot \mathrm{ha}^{-1}$ to prevent overlap and doubling of the rate.

\section{Literature Cited}

Agricultural Marketing Resource Center (AMRC). 2011. Commodity strawberry profile. 7 Nov.
2011. <http://www.agmrc.org/commodities products/fruits/strawberries/commodity_ strawberry_profile.cfm>.

California Department of Pesticide Regulation 2012. 2010 Annual statewide pesticide use report. 1 May 2012. <http://www.cdpr.ca.gov/ docs/pur/pur10rep/comrpt10.pdf $>$.

California Strawberry Commission. 2011. Varieties and season information. 21 Nov. 2011. $<$ http://www.calstrawberry.com/commission/ varieties.asp $>$.

Daugovish, O., S.A. Fennimore, and M.J. Mochizuki. 2008. Integration of oxyfluorfen into strawberry (Fragaria $\times$ ananassa) weed management programs. Weed Technol. 22:685-690.

Daugovish, O., M. Mochizuki, and S. Fennimore. 2009. Control of difficult weeds for California strawberry production. Acta Hort. 842:207210.

Dow AgroSciences LLC. 2011. GoalTender ${ }^{\circledR}$ herbicide. 16 Nov. 2011. <http://www.cdms.net/ manuf $/$ mprod.asp? $\mathrm{mp}=11 \& 1 \mathrm{c}=0 \& \mathrm{~ms}=3691 \&$ manuf $=11>$

Fennimore, S.A. and H. Ajwa. 2003. Weed management in strawberry. California Strawberry Commission, Annu. Production Res. Rpt. p. $146-154$.

Fennimore, S.A., H. Ajwa, J.S. Rachuy, S. Shem-Tov, K. Roth, J.B. Weber, and O. Daugovish. 2005. Weed management in strawberry. California Strawberry Commission, Annu. Production Res. Rpt. p. 85-98.

Fennimore, S.A., O. Daugovish, and R.F. Smith 2008. Strawberry integrated weed management. 7 Nov. 2011. <http://www.ipm.ucdavis. edu/PMG/r734700111.html>

Gilreath, J.P. and B.M. Santos. 2005. Weed management with oxyfluorfen and napropamide in mulched strawberry. Weed Technol. 19:325328.
Locascio, S.J., J.P. Gilreath, D.W. Dickson, T.A. Kucharek, J.P. Jones, and J.W. Noling. 1997. Fumigant alternatives to methyl bromide for polyethylene-mulched tomato. HortScience 32: 1208-1211.

Manning, G.R. and S.A. Fennimore. 2001. Evaluation of low-rate herbicides to supplement methyl bromide alternative fumigants to control weeds in strawberry. HortTechnology 11: 603-609.

North Carolina Crop Improvement Association. 2012. Strawberry plant varieties. 1 May 2012. $<$ http://www.nccrop.com/varieties.php/17/ Strawberry_Plants $>$.

Plant Sciences, Inc. 2012. Strawberry breeding. 1 May 2012.<http://www.plantsciences.com/cms/ 3/313/about/>

Samtani, J.B., H.A. Ajwa, J.B. Weber, G.T. Browne, S. Klose, J. Hunzie, and S.A. Fennimore. 2011 Evaluation of non-fumigant alternatives to methyl bromide for weed control and crop yield in California strawberries (Fragaria ananassa L.). Crop Prot. 30:45-51.

Shaw, D.V. and K.D. Larson. 2008. The strawberry breeding program. 2 May 2012. $<\mathrm{http} / /$ www.innovationaccess.ucdavis.edu/strawberry/ program.htm $>$.

Stall, W.M., R.C. Hochmuth, J.P. Gilreath, and T.E. Crocker. 1995. Tolerance of strawberries to preplant herbicides. Proc. Florida State Hort. Soc. 108:245-248.

U.S. Department of Agriculture-National Agricultural Statistics Survey. 2011. Noncitrus fruits and nuts 2010 summary. 1 May 2012. <http://usda01. library.cornell.edu/usda/nass/NoncFruiNu /2010s 2011/NoncFruiNu-07-07-2011.pdf>

Valent, U.S.A. Corporation. 2011. Chateau ${ }^{\circledR}$ Herbicide Label/MSDS. 16 Nov. 2011. <http://www. valent.com/agriculture/products/chateau/labelmsds.cfm>. 